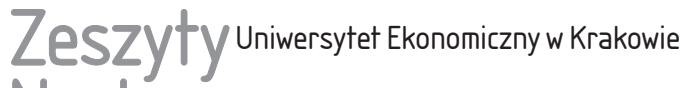 Naukowe
}

\section{Inwestorzy instytucjonalni a finansyzacja przedsiębiorstw niefinansowych: analiza wartości dla akcjonariuszy spółek sektora budowlanego*}

\section{Streszczenie}

Celem artykułu była próba weryfikacji zależności między obecnością instytucji finansowych w strukturze właścicielskiej spółek budowlanych notowanych na Giełdzie Papierów Wartościowych w Warszawie a wartością dla ich akcjonariuszy. Bazując na segmentacji akcjonariuszy na inwestorów instytucjonalnych i nieinstytucjonalnych, określono ich wpływ na zmiany wskaźnika TSR oraz indeksu MVA - wykorzystano w tym celu modele logitowe oraz analizę danych panelowych. Przeprowadzone analizy objęły lata 2004-2014 i wszystkie krajowe spółki sektora budowlanego, które były notowane na GPW w Warszawie na koniec $2014 \mathrm{r}$.

Uzyskane wyniki zasadniczo potwierdziły - zwłaszcza w odniesieniu do indeksu $M V A$ - że obecność w strukturze akcjonariatu inwestorów instytucjonalnych zwiększa

Paweł Oleksy, Uniwersytet Ekonomiczny w Krakowie, Wydział Finansów i Prawa, Katedra Rynków Finansowych, ul. Rakowicka 27, 31-510 Kraków, e-mail: oleksyp@uek.krakow.pl

Andrzej Zyguła, Uniwersytet Ekonomiczny w Krakowie, Wydział Finansów i Prawa, Katedra Rynków Finansowych, ul. Rakowicka 27, 31-510 Kraków, e-mail: zygulaa@uek.krakow.pl

* Artykuł jest wynikiem realizacji projektu badawczego dofinansowanego ze środków przyznanych Wydziałowi Finansów i Prawa Uniwersytetu Ekonomicznego w Krakowie w ramach dotacji na utrzymanie potencjału badawczego. 
prawdopodobieństwo, iż dana spółka będzie podążać ścieżką tworzenia wartości dla akcjonariuszy. Dodatkowo wyniki analiz ujawniły, że inwestorzy instytucjonalni mają pozytywny wpływ na to kryterium wartości. Fakt ten może być symptomem finansyzacji spółek w badanym sektorze.

Słowa kluczowe: finansyzacja, wartość dla akcjonariuszy, struktura własnościowa, inwestorzy instytucjonalni, instytucje finansowe.

Klasyfikacja JEL: G32, G23, L74.

\section{Wprowadzenie}

Budownictwo jako segment szeroko rozumianego sektora nieruchomości należy do tradycyjnych gałęzi gospodarki, o znaczącym, bo sięgającym ok. 6-8\% PKB (Łaszek 2015) udziale w wytwarzaniu krajowego PKB oraz widocznym oddziaływaniu na przestrzeń publiczną i społeczną. Wraz z dynamicznym rozwojem rynków finansowych i alternatywnych coraz większa liczba instytucji finansowych (banki, fundusze inwestycyjne, towarzystwa ubezpieczeniowe, fundusze emerytalne itp.) dokonuje inwestycji pośrednich na rynku nieruchomości. Dostępny zakres instrumentów jest szeroki, a jedną z możliwości inwestycyjnych jest zakup pakietów akcji w spółkach budowlanych notowanych na rynku publicznym. W konsekwencji w zależności od ostatecznej liczby nabytych udziałowych papierów wartościowych inwestorzy instytucjonalni zyskują możliwość wywierania realnego wpływu na działalność przedsiębiorstw i realizację określonych celów właścicieli. Jednym z nich w tradycyjnym ujęciu jest dążenie do maksymalizacji wartości dla akcjonariuszy.

Cel ten niekoniecznie jest zbieżny z celami pozostałych interesariuszy (pracowników, kontrahentów, społeczności lokalnych itd.), zaś jego realizacja jest następstwem strategicznych decyzji podejmowanych na posiedzeniach organów spółki, nieformalnych rozmów udziałowców z zarządzającymi czy też - w skrajnych przypadkach - presji na kadrę menedżerską wywieranej możliwością podjęcia działań potencjalnie zagrażających stabilności spółki (tj. wyjście z inwestycji poprzez sprzedaż posiadanego pakietu akcji).

Finansyzacja w ogólnym ujęciu oznacza rosnącą rolę motywów finansowych, rynków i instytucji finansowych w krajowej i międzynarodowej gospodarce (Epstein 2005). Stąd obecność inwestorów instytucjonalnych w strukturze własnościowej spółek niefinansowych i stopien ich instytucjonalnego aktywizmu determinują w znacznym stopniu skalę procesów finansyzacyjnych na poziomie mikroekonomicznym. Mogą one ujawniać się m.in. w obszarze kreowania wartości przedsiębiorstwa, w szczególności wówczas, gdy nadrzędnym celem podmiotu jest maksymalizacja wartości dla akcjonariuszy i nadanie priorytetu spełnieniu ich oczekiwań finansowych. 
Analiza roli inwestorów instytucjonalnych w strukturze właścicielskiej spółek niefinansowych, a także sposobu i zakresu ich oddziaływania na funkcjonowanie przedsiębiorstw jest $\mathrm{w}$ ostatnich dekadach przedmiotem intensywnych badań naukowych. W zależności od przyjętej perspektywy sprowadzają się one zwykle do weryfikacji stopnia koncentracji lub rozproszenia akcjonariatu (Faccio i Lang 2002, Crotty 2002, Peetz, Murray i Nienhüser 2013), realizowanej polityki dywidendowej (Grinstein i Michaely 2005, Rubin i Smith 2009, Djebali i Belanes 2015), zakresu instytucjonalnego aktywizmu (McCahery, Sautner i Starks 2016) czy zależności między strukturą właścicielską a wartością przedsiębiorstwa (Ruiz-Mallorqui i Santana-Martin 2011).

Ze względu na rozległość problematyki dotyczącej tworzenia wartości dla akcjonariuszy w niniejszym artykule skoncentrowano się jedynie na wybranych zewnętrznych miernikach tej wartości (tj. indeksie rynkowej wartości dodanej i całkowitej stopie zwrotu dla akcjonariuszy). Celem artykułu jest próba odpowiedzi na pytanie, czy istnieje zależność między obecnością inwestorów instytucjonalnych w strukturze właścicielskiej spółek budowlanych notowanych na Giełdzie Papierów Wartościowych w Warszawie (GPW) a wartością dla ich akcjonariuszy. Aby udzielić odpowiedzi na tak postawiony problem badawczy, przyjęto hipotezę szczegółową, zgodnie z którą obecność inwestorów instytucjonalnych w strukturze właścicielskiej ma pozytywny wpływ na wartość dla akcjonariuszy.

\section{Zewnętrzne mierniki wartości dla akcjonariuszy}

\subsection{Uwagi ogólne}

Podstawowym źródłem informacji dla analityków wyceniających spółki handlowe są sprawozdania finansowe. Dokumenty te ze względu na swoją wiarygodność stanowią zarazem podstawę kalkulacji tzw. wewnętrznych mierników wartości dla akcjonariuszy. Każde przedsiębiorstwo funkcjonuje jednak w otoczeniu, które oddziałuje na jego działalność, a tym samym wpływa na jego wartość. Zewnętrzne mierniki wartości dla akcjonariuszy uwzględniają ten fakt, bazując na ocenie wartości spółki przez poszczególnych uczestników rynku, czyli na wycenie rynku kapitałowego, co znajduje odzwierciedlenie w bieżącej cenie rynkowej akcji. Wśród zewnętrznych mierników wartości dla akcjonariuszy wymienić można m.in. rynkową wartość dodaną (market value added - MVA) oraz całkowitą stopę zwrotu dla akcjonariuszy (total shareholder return - TSR). 


\subsection{Rynkowa wartość dodana}

Rynkową wartość dodaną oblicza się jako różnicę pomiędzy całkowitą wartością rynkową (kapitału własnego i obcego) a całkowitym poziomem kapitału. Ściślej ujmując, $M V A$ stanowi całkowitą wartość rynkową wszystkich akcji i obligacji przedsiębiorstwa znajdujących się w obrocie pomniejszoną o całkowitą wartość kapitału wniesionego od początku funkcjonowania przedsiębiorstwa w formie akcji, obligacji, zysków zatrzymanych i kredytów bankowych. W teorii i praktyce przyjmuje się upraszczające założenie, zgodnie z którym wartość zobowiązań obciążonych odsetkami jest równa (lub bardzo bliska) ich wartości księgowej (Niemiec i Skoczylas 2007, s. 77; Duliniec 2001, s. 148). Stosując to uproszczenie, $M V A$ może być wyrażona jako różnica między rynkową wartością kapitału własnego (iloczyn rynkowej ceny jednej akcji spółki oraz liczby wyemitowanych przez nią akcji) a wartością księgową kapitału własnego, czyli:

$$
M V A_{t}=M V_{t}-B V_{t},
$$

gdzie:

$M V_{t}$ - rynkowa wartość spółki ustalona na dzień $t$,

$B V_{t}-$ księgowa wartość kapitału własnego w dniu $t$.

Ostatecznie MVA stanowi różnicę między sumą gotówki, którą akcjonariusze spółki mogliby wyprowadzić z rynku, gdyby sprzedali swoje akcje, a sumą środków pieniężnych zainwestowanych przez nich do tej pory w spółkę. Różnica ta stanowi więc wskaźnik kreacji lub spadku wartości kapitału inwestorów.

Wskaźnik MVA nie jest pozbawiony pewnych wad. Podstawowe jego mankamenty to nieuwzględnianie źródeł pochodzenia kapitału oraz pomijanie części środków finansujących aktywa. Trzeba też wspomnieć, że $M V A$ jest mierzony tylko na poziomie całego przedsiębiorstwa oraz - co równie ważne - można go wyliczyć wyłącznie dla spółek publicznych (Sobotnik 2008, s. 676). Ponadto $\mathrm{z}$ uwagi na fakt, że $M V A$ jest miernikiem mającym charakter absolutny, ocena otrzymanych wyników może prowadzić niejednokrotnie do błędnych wniosków co do poziomu tworzenia wartości dla akcjonariuszy. Charakter tego typu miernika praktycznie uniemożliwia bowiem analizę porównawczą podmiotów o zróżnicowanych rozmiarach, tj. o odmiennych wielkościach bazy kapitałowej. W ocenie efektywności gospodarowania lepsza jest wielkość relatywna (względna), którą jest tzw. standaryzowana MVA (Cwynar i Cwynar 2002, s. 403), określana też jako indeks MVA (Szczepankowski 2013, s. 103). Wskaźnik ten stanowi iloraz rynkowej wartości dodanej i wartości kapitału własnego:

$$
\text { indeks } M V A_{t}=\frac{M V A_{t}}{B V_{t-1}},
$$


W powyższej postaci $M V A$ odzwierciedla stopę efektywności zainwestowanego na początku okresu $t$ kapitału własnego, mierzoną nadwyżką wartości rynkowej nad wartością księgową kapitału własnego, i właśnie ta postać wykorzystana została w dalszej części niniejszego artykułu.

\subsection{Całkowita stopa zwrotu dla akcjonariuszy}

Całkowita stopa zwrotu dla akcjonariuszy to miernik, który w sposób najbardziej przejrzysty i bezpośredni odnosi się do pojęcia bogactwa akcjonariuszy. TSR w przeciwieństwie do $M V A$ uwzględnia nie tylko zmiany wartości kapitału akcjonariuszy, ale też gotówkę płynącą do nich ze spółek - czy to w postaci dywidend, czy środków z tytułu wykupu własnych akcji.

Całkowita stopa zwrotu dla akcjonariuszy jest więc wskaźnikiem mierzącym całkowite korzyści właścicieli spółki z aprecjacji jej rynkowego kursu i gotówkowych wypłat dokonanych w badanym okresie, wyrażone jako procent inwestycji początkowej akcjonariuszy (Cwynar i Cwynar 2002, s. 171), czyli:

$$
T S R=\frac{\left(P_{t}-P_{t-1}\right)+W}{P_{t-1}} \cdot 100 \%,
$$

gdzie:

$P_{t-1}$ - cena rynkowa akcji spółki na początku okresu pomiaru,

$P_{t}$ - cena rynkowa akcji spółki na końcu okresu pomiaru,

$W$ - wypłata gotówki dla akcjonariuszy - najczęściej dywidenda przypadająca na jedną akcję spółki w rozpatrywanym okresie pomiaru, choć uwzględnia się tu również wykup akcji, który także jest pieniężnym transferem korzyści dla akcjonariuszy.

Jak każdy wskaźnik finansowy $T S R$ posiada wiele zalet, ale też nie jest wolny od wad (Stalmach 2005, s. 83; Sobotnik 2008, s. 681). Jako zalety tego wskaźnika wymienia się najczęściej to, że TSR jest miernikiem niepodlegającym zniekształceniom na skutek polityki księgowej, posiada prostą formułę opartą na ogólnodostępnych danych oraz łączy w sobie dwie perspektywy, tj. zewnętrzną wycenę oraz wewnętrzne decyzje o dywidendzie. Wśród wad wskazuje się natomiast na dużą zależność TSR od danych rynkowych, w tym danych kształtowanych w wyniku działań spekulacyjnych, co naraża ten wskaźnik na zniekształcenia. Zastrzeżenia budzą również nieuwzględnianie inflacji, możliwość zastosowania $T S R$ wyłącznie do spółek publicznych oraz fakt, że TSR nie może być zastosowany na poziomie strategicznej jednostki biznesowej.

Mając na względzie komponenty formuły obliczeniowej TSR, należy pamiętać, że pewne wątpliwości budzi kwestia wiarygodności kursu akcji na dany dzień kurs może, ale nie musi być zniekształcony, np. przez wydarzenia gospodarcze, polityczne czy inne czynniki zewnętrzne. Kolejna wątpliwość wiąże się z wypłatą 
gotówki dla akcjonariuszy, która to pozycja zgodnie z teorią finansów obejmuje dywidendę, a także wykupy akcji. Uwzględniając powyższe uwagi, w dokonanych obliczeniach przyjęto, że: $W=D P S$ to dywidenda przypadająca na jedną akcję spółki, która w danym roku dokonała wypłaty, $P_{t-1}$ to kurs otwarcia na pierwszej sesji w danym roku, a $P_{t}$ to kurs zamknięcia na ostatniej sesji w danym roku.

\section{Inwestorzy instytucjonalni a wartość dla akcjonariuszy}

W artykule podjęto próbę weryfikacji zależności między strukturą właścicielską krajowych spółek publicznych z sektora budowlanego a wartością dla akcjonariuszy. W szczególności, bazując na segmentacji akcjonariuszy na inwestorów instytucjonalnych (finansowych) i nieinstytucjonalnych (niefinansowych), a także zróżnicowaniu grupy inwestorów instytucjonalnych pod kątem zakresu koncentracji udziałów, poddano analizie ich wpływ na zmiany dwóch rynkowych miar wartości dla akcjonariuszy, tj. indeksu rynkowej wartości dodanej (indeks MVA) i całkowitej stopy zwrotu dla akcjonariuszy (TSR). Analizą objęto lata 2004-2014 i wszystkie krajowe spółki sektora budowlanego, które były notowane na Giełdzie Papierów Wartościowych w Warszawie na koniec 2014 r. - stanowiły one wyjściową próbę badawczą. Z próby tej w dalszej kolejności w każdym kolejnym roku wyeliminowano spółki, które debiutowały na giełdzie w trakcie danego roku, ponieważ w takim przypadku pomiar rocznych TSR nie był możliwy. Dodatkowo wyeliminowano w danym roku spółki, które w tym roku miały niekompletne dane finansowe (np. w 2014 r. brak danych dla MSX Resources/Mostostal Export), co uniemożliwiało kalkulację MVA. W wyniku tak przeprowadzonych korekt otrzymano finalną próbę badawczą, składającą się z 34 podmiotów, które odpowiadały łącznie za 284 badane zdarzenia. Szczegółowe zestawienie liczebności badanej próby w poszczególnych latach przedstawiono w tabeli 1 .

Tabela 1. Liczebność analizowanej próby badawczej w latach 2004-2014

\begin{tabular}{|l|c|c|c|c|c|c|c|c|c|c|c|c|}
\hline Lata & 2004 & 2005 & 2006 & 2007 & 2008 & 2009 & 2010 & 2011 & 2012 & 2013 & 2014 & Ogółem \\
\hline Próba & 17 & 18 & 18 & 18 & 24 & 28 & 28 & 32 & 34 & 34 & 33 & 284 \\
\hline
\end{tabular}

Źródło: opracowanie własne na podstawie Roczników Giełdowych z lat 2005-2015.

W pierwszym etapie analizy wykorzystano model regresji logit, aby zweryfikować, czy w przypadku spółek giełdowych należących do sektora „budownictwo”:

- po pierwsze, obecność w strukturze akcjonariatu danej spółki inwestora instytucjonalnego ma pozytywny wpływ na prawdopodobieństwo, że spółka ta wykreuje wartość dla akcjonariuszy, 
- po drugie, posiadanie przez daną spółkę dominującego inwestora nieinstytucjonalnego ma negatywny wpływ na prawdopodobieństwo, że spółka stworzy wartość dla akcjonariuszy.

Dokonując analizy logit, na wstępie założono, że zmienną zależną jest zmienna zerojedynkowa, określona na podstawie:

- w przypadku pierwszej grupy modeli: indeksu $M V A$, który przyjmuje wartość 1 , jeśli spółka w roku $t$ charakteryzowała się dodatnią wartością indeksu $M V A\left(M V A_{t}>0\right)$, i $0 \mathrm{w}$ przeciwnym razie,

- w przypadku drugiej grupy modeli: wskaźnika TSR, który przyjmuje wartość 1 , jeśli spółka w roku $t$ charakteryzowała się nieujemną wartością wskaźnika $\left(T S R_{t}>0\right)$, i $0 \mathrm{w}$ przeciwnym razie.

Zmiennymi niezależnymi regresji były natomiast:

- udział inwestora instytucjonalnego (FIN) jako procent głosów na WZA, czyli łączny skumulowany udział inwestorów instytucjonalnych, którzy w danej spółce na koniec roku obrachunkowego $t$ występowali w strukturze jej akcjonariatu,

- udział dominującego inwestora nieinstytucjonalnego $\left(N_{-} F I N\right)$ jako procent głosów na WZA, czyli udział największego pojedynczego inwestora nieinstytucjonalnego, który występował w strukturze akcjonariatu danej spółki na koniec roku obrachunkowego $t$.

W obydwu przypadkach dane dla każdego roku zostały uzyskane z bazy danych Notoria Serwis.

W tabeli 2 zaprezentowano przewidywane relacje między omówionymi zmiennymi a prawdopodobieństwem wypłaty dywidendy w spółce.

Tabela 2. Przewidywane relacje pomiędzy prawdopodobieństwem wypłaty dywidendy a cechami charakterystycznymi spółki

\begin{tabular}{|l|l|c|}
\hline Zmienna & \multicolumn{1}{|c|}{ Formuła } & Oczekiwany znak korelacji \\
\hline FIN & $\sum \%$ głosów na WZA inwestorów instytucjonalnych & dodatni \\
\hline N_FIN & $\begin{array}{l}\text { \% głosów na WZA największego pojedynczego } \\
\text { inwestora nieinstytucjonalnego }\end{array}$ & ujemny \\
\hline
\end{tabular}

Źródło: opracowanie własne.

Omówione powyżej zmienne użyte zostały następnie do budowy modeli logitowych. W tabeli 3 przedstawiono sześć oszacowanych modeli logitowych. $\mathrm{Z}$ zamieszczonych w tabeli danych wynika, że wartości ocen parametrów występujących przy zmiennych $F I N$ w każdym z przedstawionych modeli są dodatnie, co oznacza, że obecność w strukturze akcjonariatu inwestorów instytucjonalnych zwiększa prawdopodobieństwo, iż spółka będzie podążała ścieżką tworzenia wartości dla akcjonariuszy. W szczególności jednak tylko w modelach skonstru- 
owanych dla kryterium wartości wyrażonego indeksem $M V A$ parametry były nie tylko dodatnie, ale też istotne statystycznie. Parametry oszacowane dla zmiennej $N_{-}$FIN są statystycznie istotne tylko w jednym z przedstawionych modeli (dla $T S R$ ), jednak ich znaki ocen są zgodne z oczekiwaniami i we wszystkich modelach ujemne, co sugeruje, że obecność w spółce dominującego akcjonariusza nieinstytucjonalnego zwiększa prawdopodobieństwo redukcji wartości dla akcjonariuszy.

Tabela 3. Modele logitowe

\begin{tabular}{|l|c|c|c|c|c|c|}
\hline \multirow{2}{*}{ Wyszczególnienie } & \multicolumn{3}{c|}{ Dla indeksu $M V A$} & \multicolumn{3}{c|}{ Dla TSR } \\
\cline { 2 - 7 } & $M_{-} l a$ & $M_{-} 2 a$ & $M_{-} 3 a$ & $M_{-} 1 b$ & $M_{-} 2 b$ & $M_{-} 3 b$ \\
\hline Wyraz wolny & & & & & & \\
Ocena parametru & $-0,2023$ & 0,3806 & $-0,3377$ & $-0,1129$ & 0,3968 & 0,2907 \\
wartość $p$ & 0,2023 & 0,0823 & 0,2777 & 0,4671 & 0,0706 & 0,3441 \\
błąd standardowy & 0,1583 & 0,2182 & 0,3105 & 0,1551 & 0,2186 & 0,3068 \\
\hline FIN & & & & & & \\
Ocena parametru & 2,9509 & - & 3,1787 & 1,1186 & - & 0,4462 \\
wartość $p$ & 0,0011 & - & 0,0017 & 0,1605 & - & 0,6241 \\
błąd standardowy & 0,8939 & - & 1,0017 & 0,7950 & - & 0,9095 \\
\hline$N \_F I N$ & & & & & & \\
Ocena parametru & - & $-0,6276$ & $-0,2977$ & - & $-1,0298$ & $-0,8904$ \\
wartość $p$ & - & 0,2169 & 0,6121 & - & 0,0450 & 0,1288 \\
błąd standardowy & - & 0,5072 & 0,5863 & - & 0,5115 & 0,5844 \\
\hline Całkowita strata & 189,84 & 195,23 & 189,71 & 195,82 & 194,76 & 194,64 \\
\hline Wartość statystyki chi-kwadrat & 12,31 & 1,53 & 12,57 & 2,02 & 4,12 & 4,36 \\
\hline Wartość $p$ modelu & 0,0005 & 0,2147 & 0,0018 & 0,1554 & 0,0423 & 0,1129 \\
\hline
\end{tabular}

Źródło: obliczenia własne na podstawie danych z bazy Notoria Serwis.

Podejmując dalsze badania nad wpływem inwestorów instytucjonalnych na wartość dla akcjonariuszy, na początek przyjęto dwie klasyfikacje logiczne (zerojedynkowe), a mianowicie:

- F-all_N-określona na podstawie udziału w głosach na WZA ,największego akcjonariusza", która przyjmuje wartość 1 , jeśli w spółce takim akcjonariuszem $\mathrm{w}$ roku $t$ byli łącznie inwestorzy instytucjonalni lub indywidualny inwestor instytucjonalny, i $0 \mathrm{w}$ przeciwnym razie,

- Fob_bzF - określona na podstawie obecności w strukturze akcjonariuszy inwestora instytucjonalnego według udziału w głosach na WZA, która przyjmuje wartość 1 , jeśli w spółce w roku $t$ był inwestor instytucjonalny, i 0 w przeciwnym razie.

W obydwu przypadkach dane dla każdego roku zostały uzyskane z bazy danych Notoria Serwis. 
W celu zweryfikowania kierunku i siły wpływu inwestorów instytucjonalnych oraz nieinstytucjonalnych według wspomnianych klasyfikacji, tj. $F$-all_N i $F o b \_b z F$, na wartość dla akcjonariuszy wyrażoną indeksem $M V A$ lub TSR w kolejnych analizach wykorzystano modele dla danych panelowych o efektach losowych (random effect). Mając jednak na uwadze fakt, że w modelach tych efekty indywidualne mogłyby być bądź efektami ustalonymi (fixed effects), bądź efektami losowymi (random effects), dodatkowo przeprowadzono test Hausmana, aby zweryfikować hipotezę o losowości tych efektów. W tabeli 4 przedstawione zostały wyniki estymacji danych panelowych.

Tabela 4. Wyniki estymacji danych panelowych dla zmiennej „indeks $M V A ”$ oraz zmiennej TSR - model o zmiennych efektach

\begin{tabular}{|c|c|c|c|c|}
\hline \multicolumn{5}{|c|}{$\begin{array}{l}\text { Estymacja Losowe efekty (GLS) - } 284 \text { obserwacje } \\
\text { Szereg czasowy długości: minimum 3, maximum } 11\end{array}$} \\
\hline Wyszczególnienie & Współczynnik & $\begin{array}{c}\text { Błąd } \\
\text { standardowy }\end{array}$ & $z$ & Wartość $p$ \\
\hline \multicolumn{5}{|c|}{ Zmienna zależna „indeks $M V A ”$} \\
\hline const & $-1,5702$ & 1,2390 & $-1,267$ & 0,2050 \\
\hline$F o b \_b z F$ & 4,1483 & 1,5829 & 2,621 & $0,0088^{* * *}$ \\
\hline \multicolumn{5}{|c|}{$\begin{array}{l}\text { Test Hausmana - asymptotyczna statystyka testu: chi-kwadrat }(1)=1,6865 \\
\text { z wartością } p=0,1941\end{array}$} \\
\hline const & $-0,0879$ & 0,8615 & $-0,1021$ & 0,9187 \\
\hline$F$-all_N & 5,2779 & 1,92302 & 2,745 & $0,0061^{* * *}$ \\
\hline \multicolumn{5}{|c|}{$\begin{array}{l}\text { Test Hausmana - asymptotyczna statystyka testu: chi-kwadrat }(1)=0,4873 \\
\mathrm{z} \text { wartością } p=0,4851\end{array}$} \\
\hline \multicolumn{5}{|c|}{ Zmienna zależna $T S R$} \\
\hline const & 0,1725 & 0,0921 & 1,8739 & $0,0610^{*}$ \\
\hline$F o b \_b z F$ & 0,0076 & 0,1177 & 0,0646 & 0,9485 \\
\hline \multicolumn{5}{|c|}{$\begin{array}{l}\text { Test Hausmana - asymptotyczna statystyka testu: chi-kwadrat }(1)=2,7576 \\
\mathrm{z} \text { wartością } p=0,0968\end{array}$} \\
\hline const & 0,1889 & 0,06409 & 2,9473 & $0,0032^{\text {**** }}$ \\
\hline$F$-all_N & $-0,0581$ & 0,1431 & $-0,4063$ & 0,6845 \\
\hline
\end{tabular}

*** zmienna istotna przy poziomie istotności 0,$01 ;{ }^{*}$ zmienna istotna przy poziomie istotności 0,1 .

Źródło: opracowanie własne na podstawie danych Notoria Serwis.

Jak wynika z danych zaprezentowanych w tabeli 4, przeprowadzone testy Hausmana w każdym przypadku potwierdziły słuszność zastosowania modelu 
dla danych panelowych o efektach losowych. Można zauważyć również, że zamieszczone w tabeli 4 wyniki obliczeń, wskazując na kierunek oddziaływania inwestorów instytucjonalnych na wartość dla akcjonariuszy, są zasadniczo zgodne z wnioskami płynącymi z wcześniejszej analizy logitowej. W szczególności w odniesieniu do zmiennej zależnej „indeks $M V A$ ” można stwierdzić, że ocena punktowa parametrów występujących przy zmiennej niezależnej ( $F$-all_N i $\left.F o b \_b z F\right)$ za każdym razem była dodatnia i istotna statystycznie, co oznacza, że inwestorzy instytucjonalni mieli pozytywny wpływ na to kryterium wartości. W przypadku zmiennej zależnej TSR ocena punktowa parametrów występujących przy zmiennej niezależnej raz była dodatnia, a raz ujemna, ponadto wyniki świadczą o tym, że zaobserwowane zmiany w poziomie TSR jako odpowiednik obecności inwestorów instytucjonalnych należy uznać za statystycznie nieistotne.

Aby uzyskać dokładniejszy obraz, już nie tylko co do kierunku i siły, ale i różnic między analizowanymi dwiema grupami akcjonariuszy, analizie ANOVA poddano wszystkie spółki i obliczone dla nich wartości indeksu MVA i TSR, oczekując odpowiedzi na pytanie, czy istnieje wpływ czynnika klasyfikującego na wartość wskaźnika. Założono przy tym, że:

- obserwowaną zmienną objaśnianą są obliczone dla poszczególnych spółek wartości indeksu MVA oraz wskaźnika TSR,

- czynnikiem klasyfikującym, czyli zmienną niemierzalną, jest natomiast wcześniej dokonany podział podmiotów na spółki z inwestorami instytucjonalnymi i nieinstytucjonalnymi według przyjętych klasyfikacji $F$-all_N i Fob_bzF.

Tabela 5. Analiza wariancji dla badanych zmiennych „,indeks MVA” i TSR

\begin{tabular}{|c|c|c|c|c|c|c|c|c|c|c|}
\hline \multirow{2}{*}{ Wskaźnik } & \multicolumn{2}{|c|}{$\begin{array}{l}\text { Średnia } \\
\text { wartość }\end{array}$} & \multirow{2}{*}{$S S B$} & \multirow{2}{*}{$\begin{array}{c}\text { Liczba } \\
\text { stopni } \\
\text { swo- } \\
\text { body }\end{array}$} & \multirow{2}{*}{$M S B$} & \multirow{2}{*}{ SSE } & \multirow{2}{*}{$\begin{array}{c}\text { Liczba } \\
\text { stopni } \\
\text { swo- } \\
\text { body }\end{array}$} & \multirow{2}{*}{$M S E$} & \multirow{2}{*}{$F$} & \multirow{2}{*}{$\begin{array}{l}\text { War- } \\
\text { tość } p\end{array}$} \\
\hline & 0 & 1 & & & & & & & & \\
\hline \multicolumn{11}{|c|}{ Indeks $M V A$} \\
\hline$F-a l l \_N$ & $-0,09$ & 5,19 & 1000 & 1 & 1000 & 50000 & 282 & 200 & 7,53 & 0,006 \\
\hline$F o b \_b z F$ & $-1,57$ & 2,58 & 1000 & 1 & 1000 & 50000 & 282 & 200 & 6,87 & 0,009 \\
\hline \multicolumn{11}{|c|}{$T S R$} \\
\hline$F-a l l \_N$ & 0,19 & 0,13 & 0,2 & 1 & 0,2 & 300 & 282 & 0,9 & 0,17 & 0,685 \\
\hline Fob_bzF & 0,17 & 0,18 & 0,004 & 1 & 0,004 & 300 & 282 & 0,9 & 0,00 & 0,940 \\
\hline
\end{tabular}

Objaśnienie: tabela pokazuje średnią wartość zmian wskaźnika TSR i indeksu MVA w podziale na dwie analizowane grupy $(0 / 1)$. Przedział odrzuceń $\mathrm{H}_{0}$ wynosi $\langle 3,87 ;+\infty)$.

Źródło: opracowanie własne na podstawie danych Notoria Serwis. 
W ramach hipotezy zerowej założono, że warunkowe wartości określonego wskaźnika (indeksu MVA lub TSR) są takie same w analizowanych dwóch grupach podmiotów. Weryfikując tę hipotezę, przyjęto poziom istotności $\alpha=0,05$. Z tablic statystycznych rozkładu Fishera-Snedecora odczytano, przy zadeklarowanym poziomie istotności, krytyczny poziom statystyki $F_{0,05 ; 1 ; 280}=3,87$, co wyznaczyło przedział odrzuceń $\mathrm{H}_{0}$, który wynosi $\langle 3,87 ;+\infty)$. Rezultaty analizy zaprezentowano w tabeli 5.

Zamieszczone w tabeli 5 wyniki obliczeń, niezależnie od klasyfikacji, wskazują jednoznacznie, że w odniesieniu do kryterium wartości wyrażonym indeksem $M V A$, niezależnie od klasyfikacji, istnieje statystycznie istotna różnica pomiędzy dwiema analizowanymi grupami akcjonariuszy. W szczególności można zauważyć, że spółki posiadające w strukturze właścicielskiej inwestora instytucjonalnego, w odróżnieniu od spółek, które takiego inwestora nie mają, kreują większą wartość dla swoich właścicieli.

\section{Zakończenie}

Zaprezentowane w artykule wyniki analiz ukazały, w szczególności w odniesieniu do indeksu $M V A$, że obecność w strukturze akcjonariatu spółek z branży budowlanej inwestorów instytucjonalnych zwiększała prawdopodobieństwo, iż spółka będzie podążała ścieżką tworzenia wartości dla akcjonariuszy. Dodatkowo wyniki te ujawniły, iż inwestorzy instytucjonalni mieli pozytywny wpływ na to kryterium wartości, a także, że spółki posiadające inwestora instytucjonalnego, w odróżnieniu od spółek, które takiego inwestora nie miały, były w większym stopniu ukierunkowane na generowanie wartości dla swoich właścicieli.

Fakt ten może świadczyć o zachodzących procesach finansyzacyjnych na poziomie mikroekonomicznym, co jednak nie musi przekładać się na kreowanie zrównoważonego rozwoju zarówno przedsiębiorstw, jak i ich otoczenia. Dalsze badania nad tym zjawiskiem powinny koncentrować się na separacji poszczególnych typów instytucji finansowych w ramach danej struktury właścicielskiej, jak również weryfikacji siły i zakresu ich faktycznego oddziaływania na wyniki działalności spółek oraz przełożenia na korzyści dla pozostałych interesariuszy.

\section{Literatura}

Crotty J. (2002), The Effects of Increased Product Market Competition and Changes in Financial Markets on the Performance of Nonfinancial Corporations in the Neoliberal Era, Political Economy Research Institute Working Paper, nr 44, PERI, Amherst. 
Cwynar A., Cwynar W. (2002), Zarządzanie wartościa spółki kapitałowej. Koncepcje, systemy, narzedzia, FRR, Warszawa.

Djebali R., Belanes A. (2015), On the Impact of Family versus Institutional Blockholders on Dividend Policy, ,Journal of Applied Business Research”, vol. 31, nr 4, https://doi. org/10.19030/jabr.v31i4.9320.

Duliniec A. (2001), Struktura i koszt kapitału w przedsiębiorstwie, Wydawnictwo Naukowe PWN, Warszawa.

Epstein G. (2005), Introduction: Financialization and the World Economy, http://www. peri.umass.edu (data dostępu: 23.08.2016).

Faccio M., Lang L.H.P. (2002), The Ultimate Ownership of Western European Corporations, ,Journal of Financial Economics”, vol. 65, nr 3, https://doi.org/10.1016/s0304405x(02)00146-0.

Grinstein Y., Michaely R. (2005), Institutional Holdings and Payout Policy, „The Journal of Finance", vol. 60, nr 3, https://doi.org/10.1111/j.1540-6261.2005.00765x.

Łaszek J. (2015), Raport branżowy ISR: Monitoring budownictwa, budownictwo kubaturowe (PKD 41) w 2014 r., Małopolska Szkoła Administracji Publicznej Uniwersytetu Ekonomicznego w Krakowie, Kraków

McCahery J.A., Sautner Z., Starks L.T. (2016), Behind the Scenes: The Corporate Governance Preferences of Institutional Investors, „The Journal of Finance”, vol. 71, nr 6, https://doi.org/10.1111/jofi.12393.

Niemiec A., Skoczylas W. (2007), Mierniki monitorowania wartości przedsiębiorstwa (w:) Determinanty i modele wartości przedsiębiorstw, red. W. Skoczylas, PWE, Warszawa.

Peetz D., Murray G., Nienhüser W. (2013), The New Structuring of Corporate Ownership, „Globalizations”, vol. 10, nr 5.

Rubin A., Smith D.R. (2009), Institutional Ownership, Volatility and Dividends, „Journal of Banking and Finance", vol. 33, nr 4, https://doi.org/10.1016/j.jbankfin.2008.11.08.

Ruiz-Mallorqui M.V., Santana-Martin D.J. (2011), Dominant Institutional Owners and Firm Value, ,Journal of Banking \& Finance”, vol. 35, nr 1, https://doi.org/10.1016/ j.jbankfin.2010.07.020.

Sobotnik R. (2008), Całkowita stopa zwrotu spółek notowanych na GPW w Warszawie (w:) Value Based Management. Koncepcje, narzędzia, przykłady, red. A. Szablewski, K. Pniewski, B. Bartoszewicz, Poltex, Warszawa.

Stalmach R. (2005), Zarzadzanie firma w interesie akcjonariuszy, Difin, Warszawa.

Szczepankowski P. (2013), Determinanty wartości rynkowej spółek kapitałowych wczesnej fazy rozwoju, Vizja Press \& IT, Warszawa.

\section{Institutional Investors and the Financialisation of Construction Companies in Poland: A Shareholder Value Approach}

(Abstract)

The study examines how the presence of financial institutions in the ownership structure of non-financial corporations affects shareholder value. Based on the segmentation of shareholders (institutional and non-institutional investors), their impact on changes in the TSR and the MVA index was examined using logit models and panel 
data analysis. The analysis covers the years 2004-2014 and all the national construction companies listed on the Warsaw Stock Exchange at the end of 2014.

The results confirm, particularly with respect to the MVA, that the presence of institutional investors in the shareholder structure increases the likelihood that the company will maximise shareholder value. It also revealed that institutional investors had a positive impact on this value criterion. This fact may be a symptom of financialisation in the construction sector.

Keywords: financialisation, shareholder value, ownership structure, institutional investors, financial institutions. 